\title{
Schmidt Erika Brassai és az idegen nyelvek oktatása
}

I. Kezdetben csupán nyelvoktatási kérdések iránt érdeklődőként terelődött figyelmem Brassai idegennyelv-oktatási mủvére, a Die reform des Sprachunterrichts in Europa-ra (Összehasonlító Irodalomtörténeti Lapok, 1882). Ennek, a nyelvoktatási kérdésekben talán legátfogóbbnak mondható münek az olvasása közben azonban nemcsak módszertani értékekre leltem, hanem leíró nyelvészeti gondolatai is felkeltették érdeklődésemet. Meg kell azonban jegyeznem, hogy Brassaival nyelvtudományi tekintetben is érdemben foglalkozó Fitz József és Gál Kelemen a Sprachunterricht értékelésekor - mondhatni teljesen érthetően - nem leíró nyelvészeti kérdések szóbahozatalában látja a mü jelentőségét.

II. A következőkben éppen a fentiek figyelemben vételével, két kérdéskörre szeretnék összpontosítani: a nyelvoktatás kérdéseire, valamint Brassainak a mondattal kapcsolatos fejtegetéseire.

\section{A) A nyelvoktatás kérdései}

A Sprachunterricht-ben Brassai áttekinti az idegennyelv-tanítás módszertanának történeti fejlödését, bemutatja a különböző eljárások erényeit, hibáit és saját, önállóan kidolgozott módszerét. A történeti áttekintésben az értékelés alapvető szempontja ez: a tankönyvírók és általában a nyelvtanárok felismerik-e a nyelvet beszélőnek és a nyelvet éppen tanulónak a nyelvtannal szembeni viszonyban mutatkozó különbséget.

A Brassai emlegette Donatus, Meidinger, illetőleg Kühner-féle grammatikáról nem állítható, hogy figyelembe vennék a nyelv meg a nyelvtanítás közti eltéréseket. A nyelvtani rendszert deduktív módszerrel írják le, a diáktól tehát csak memorizását várnak el. ${ }^{123}$ Gyökeres változást az induktív módszer bevezetése hozott. A szöveg ennek alkalmazásakor nem a szabály illusztrálását szolgálja, hanem elvonását teszi lehetővé. Ez pedig a diák önálló gondolkodását tételezi föl.

A továbbiakban Jacotot kissé talán szélsőséges módszerét érinti. e módszer kudarcát Brassai nem az analízis és induktív szabályalkotás hiányában, hanem az így tanítani képes tanárok hiányában látja.

Vizsgálja ezen kívül Francois Gouin 1880-ban publikált nyelvtanítási és - tanulási módszerét (Exposé d'une nouvelle méthode linguistique. L'art d'enseigner et d'étudier des langues). ${ }^{124} \mathrm{a}$ Gouin-módszerrel kapcsolatban természetesen csak a Brassai által elfogadott felismerésekről szólnék. A legfontosabbak a következők:

Gouin szerint az idegen nyelvek tanulásakor is a gyermek nyelvtanulási metódusát kellene reprodukálni.

A beszéd, ezen belül a „mondatok” szerepe, Jacotot-nál, Gouin-nél is döntő. A szavakat ti. „mondatban" kell megismerni.

A gyermek, idézi Gouin-t, elsősorban a mondat legfontosabb, legnyomatékosabb részét hallja. Ez pedig - példái alapján - az igei állítmány.

\footnotetext{
„Németországban évente harcmincezer könyv jelenik meg. Hol van Lichtenberg? Hol van Lichtenberg? Hol van Lichtenberg?"

${ }^{123}$ Meidinger 1783-ban megjelent francia grammatikája német példákat ajánl fordításra. Ugyanezt teszi a klasszikus nyelvre vonatkozóan. Kühner kb. Hatvan év múlva klasszikus nyelvekre vonatkozóan. A fentiek Donatus-szal szemben ennyi újat hoznak.

${ }^{124}$ Brassai szerint nem derül ki pontosan, hogy Gouin idegen nyelvként a francia vagy a német nyelvet kívánja-e tanítani.
} 
Felismeri Brassai az igeidő és a mondat ideje közti eltéréseket (napjainkban ezzel föként Kiefer Ferenc foglalkozik). ${ }^{125}$

Felfigyel a mondatalkotás és - megértés ellentétes irányú folyamatára (ez az, amit a Dependenzgrammatik a beszélő szemszögéből a hierarchikus, logikai rend lineáris, nyelvtani renddé alakulásának nevez, illetőleg visszaalakulásának a megértés folyamán). ${ }^{126}$

Brassai mindezt tizenkét pontban összefoglalt általános oktatásmódszertani elvekkel és magára a nyelvoktatásra vonatkozó kilencpontos módszerjegyzékkel egészíti ki. Gouin müvének kritikai tárgyalásakor saját, az 1867-es akadémiai székfoglalóban kifejtett nézeteit ismétli meg. ${ }^{127}$ Brassai persze - Gouinnel ellentétben - már 1867-ben sem kipróbálandó, hanem már kipróbált elvekről beszél. Hiszen több kiadást megért francia és német nyelvkönyvek állnak mögötte (Ingyen tanitó francia nyelvmester, Okszerü Vezér a német nyelv tanulásában). Módszerét a Sprachunterricht-ben különben jellemzően a latin nyelv példáján mutatja be, szerkezeti szempontból a nyelvkönyvekhez képest jelentős eltérés nélkül.

Dolgozatomban Brassai néhány különösen elöremutató „fogására” is utalnék.

Fontosnak tartja a fordítás együttes alkalmazását, a háromszintes ismétlést (korábban végzett gyakorlatok, múveletek felidézése, a korábban tanult szavak új formákba alakítása, új formák visszaalakítása korábban tanultakba), kezdetben részleges, fokozatosan kiegészített fönév- és igeragozási sorok összeállítását, mégpedig önállóan a diák által.

Brassai szerint a gyakorlatok elvégzése természetesen csak mondatban képzelhető el. Így bontakozik ki szükségszerüen a második kérdéskör:

B) Brassainak a mondattal kapcsolatos fejtegetései

1. A német nyelvleírási terminológia egyik hiányosságára hívja fel a figyelmet. A németben a nyelvtani mondat megjelölésére alkalmazott Satz helyett új, megfelelö megnevezést lát szükségesnek. A Satzot azért nem vetné el, mert logikai fogalom, mely tehát kvalitatív, a nyelvtani mondatnak alárendelt fogalom. De nem fogadja el a periode megnevezést sem, mivel ez kvalitatív fogalom. ${ }^{128}$ Az elözőkkel szemben ő a phrase terminust alkalmazza.

A periode-t Brassai 'összetett mondat' értelemben használja. Olyan phrase ez, amelynek összetevői maguk is phrasek. A periode a mondatrészek egyik módosulási lehetőségeként jön létre. ${ }^{129}$ Mivel, - mint ahogyan ma mondanók - az egyszerü mondatrészek mellékmondattá alakíthatók. Ez Brassainál így jelenik meg: „A periode tartalmazta phrasékat az egyszerü vagy bővített phrase azon részeinek tulajdonsága alapján különböztetem meg, amelyeket képviselnek. Így vannak kiegészitö phrasék, elsődleges és másodlagos melléknévi phrasék, továbbá az effajta phrasék halmozásai." "130

2. A Sprachunterricht-ben Brassai szól a modern szövettani megjelöléssel aktuális tagolásnak nevezett kérdésröl is, mellyel különben már német nyelvtanában is szembesült. ${ }^{131}$ Abban ugyanis a következő tagolást javasolja: nevezzük szubjektumnak azt, ami az ige elött áll, f ü g g e t l e n ü 1

\footnotetext{
${ }^{125}$ L. tőle Az elöfeltevések elmélete. Bp., 1983.

${ }^{126}$ Th. Lewandowski, Lingwistisches Wörterbuch. I. Quelle \& Meyer, Heidelberg-Wiesbaden, 1991. 214. 1.

${ }^{127}$ Gouin müvét a német nyelvészekkel is Brassai ismertette meg. Lást Fitz József, Brassai Sámuel. Bp., 1911. 71.1.

$128, \ldots$ der satz ist eine qualitative der phrase als genus, wie andereseits die periode auch eine solche, jedoch quantitative ist" (az idézetek és szavak eredeti helyesírását itt is, a továbbiakban is megőrzöm S.E.): Sprachtunterricht. Kolozsvár. Sumptibus Editorum Actorum Comprationis Litterarum Universarum. London, Trübner \& CO. 6. 1. - Az idézett müvek helyesírását mindig megőriztem. S. E.

${ }^{129}$ a mondatrészek másik módosulási lehetősége a halmozás. Ez bővített mondatrészeket és ebben az értelemben vett bővített mondatokat eredményez: „[Durch häufung] wird in der tat nur das bezügliche element erweitert, aber die benennung wird auf die phrase selbst übertragen und sie selbst als eine «erweiterte» genannt”: Sprachunterricht 81. 1.

130 „Ich unterscheide die in der periode enthaltenen phrasen je nach der beschaffenheit der bestandteile des einfachen und erweiten phrase, die sie vertreten. Es gibt mithin ergänzungsphrasen, primäre und secundäre beiwortsphrasen, und dann auch häufungen von derlei phrasen": Sprachunterricht 84.1.

${ }^{131}$ Elméleti ésgyakorlati német nyelvtan. Kolozsvár. Stein János M.K. egyetemi könyvkereskedés, 1896.
} 
s zó f a j i é r t é k é t ő 1 és ebből következő mondatgrammatikai szerepétől. Ezt a gondolatot a Sprachunterricht-ben a következőképpen viszi tovább. A szubjektum a mondat első része, mindig ismert, mellékhangsúllyal bír. A predikátum mindig az ismeretlen rész, viszont ebben a rejlik a mondat lényege, mindig itt az ige (a kopulát kivéve), erre esik a beszéd és a mondathangsúly. Mindez akkor is érvényes, ha a szubjektum a második helyre kerül a mondatban.

Efféle mondattagolás alapján vezeti be 1869-ben Georg von Gabelentz a pszichológiai alany és állítmány fogalmát. ${ }^{132}$ Vonatkozó nézeteit Brassai szóban már a 40-es években, 1853-ban a Pesti naplóban pedig írásban is kifejtette. A mondat két részének megnevezésére a phrasenfuss 'mondatláb' és phrasenleib 'mondattest' megjelöléseket javasolja.

3. A nyelvoktatás alapja - tanítja Brassa - az egyszerü tőmondat. Ez állhat egyetlen állítmányi szerepű igéből, vagy alany és állítmány „testes” kapcsolatából, melyben az alany szerepét fónév vagy személyes névmás töltheti be. A phrase mind a fónévi, mind a személyes névmási alany esetében kétféleképpen hangsúlyozható és ennek megfelelően kétféleképpen dekódolható. Brassai példamondata „Frater dormit,” egyaránt válaszolhat a „qui dormit?” és „quid agit?” kérdésre. Ez a megállapítás különösen fontos a személyes névmásokkal kapcsolatban, mivel ezek kitétele a latinban és a „vele lélekben rokon” (értsd: neolatin) nyelvekben nem kötelező. Kitételükkor a személyes névmások (,persönliche fürwörter”) viszont „nem csupán megjelölöi a cselekvő személynek, hanem mindig nyomatékos kiegészítésként használatosak, következésképpen mindig hangsúlyosak. A phrasék tehát, amelyek ezeket [ti. személyes névmásokat - kiegészítés tőlem S.E.] tartalmazzák, többnyire egyértelmüek."133

Ezt a sajátságot a magyar szakirodalom, legalábbis Károly Sándor tanulmánya óta, a szövegmondatnak tulajdonítja. ${ }^{134}$ Kontextus hiányakor azonban ezeket a mondatokat nem tekinthetjük szövegmondatoknak.

Ezzel kapcsolatban Elekfi László az 1988-as budapesti nyelvészkongresszuson a Károly-féle dichotómia felülvizsgálatát javasolja. ${ }^{135}$ Elekfi szerint ugyanis „a rendszermondat és a megnyilatkozás közé is be kell iktatnunk még egy fogalmat, a megnyilatkozás-típust”.

\footnotetext{
132 Gabelentz értekezését, az „Ideen zu einer vergleichenden syntax. Wort und satzstellung”-ot idézi is Brassai, Sprachunterricht 87. 1 .

${ }^{133}$ [Die nominative der persönlichen fürwörter] ,sind in der lateinischen und anderen ihr geistig verwandten sprechen keineswege blosee bezeichner der handelnden oder leidenden person, sondern werden stets als nachdrückliche ergänzungen gebraucht, foglich erhalten sie immer accente. Phrasen also, die sie enthalten, sind gewöhnlich nur eindeutig". Sprachunterricht 74. 1.

${ }^{134}$ L. tőle: Mondat és megnyilatkozás: Néprajz és Nyelvtudomány 24-5 (1980-1981). 49-62.

135 L. tőle: a mondat fogalmának alakulása Brassai mondatszemléletében. In: tanulmányok a magyar nyelvtudomány történetének témaköréből. Szerk.: Kiss Jenő és Szűts László. Akadémiai Kiadó. Bp., 1991. 150-5.
} 
III. Mint a szakirodalomból kiderült, a Brassai mondatkoncepciójával foglalkozók megállapításaikat elsősorban a következő müvekre alapozták: Tudományrend a kolozsvári unitarium collegium alsóbb osztályaiban (Vasárnapi Újság 505. sz. 25-26 hasáb); Okszerü Vezér a német nyelv tanulásában I, II (1845, 1847); Tapogatózások a magyar nyelv körül (Pesti Napló 1852. 802-3); Logika, lélektani alapon fejtegetve (Pest, 1858).

A Sprachunterricht áttanulmányozás azonban, mint a fentiekből talán kitetszik, feljogosít arra, hogy ezt a müvet a Brassai-féle mondatkoncepció egyik figyelmen kívül hagyható forrásaként tartsuk számon. 